\title{
Regulated control of melanin-concentrating hormone receptor 1 through posttranslational modifications
}

\author{
Yumiko Saito*, Akie Hamamoto and Yuki Kobayashi \\ Graduate School of Integrated Arts and Sciences, Hiroshima University, Hiroshima, Japan
}

Edited by:

Sho Kakizawa, Kyoto University, Japan

Reviewed by:

Shigeki Takeda, Gunma University, Japan

Qun Yong Zhou, University of

California, USA

*Correspondence:

Yumiko Saito, Graduate School of Integrated Arts and Sciences,

Hiroshima University, 1-7-1

Kagamiyama, Higashi-Hiroshima,

Hiroshima 739-8521, Japan

e-mail:yumist@hiroshima-u.ac.jp
Melanin-concentrating hormone $(\mathrm{MCH})$ is a hypothalamic neuropeptide that plays an important role in feeding behavior. It activates two G-protein-coupled receptors, MCHR1 and $\mathrm{MCHR} 2$, of which MCHR1 is the primary regulator of food intake and energy homeostasis in rodents. In mammalian cells transfected with $\mathrm{MCHR} 1, \mathrm{MCH}$ is able to activate multiple signaling pathways including calcium mobilization, extracellular signal-regulated kinase activation, and inhibition of cyclic AMP generation through Gi/o- and Gq-coupled pathways. Further evidence suggests that MCHR1 is regulated through posttranslational modifications, which control its intracellular localization and provide appropriate cellular responses involving G-protein signaling. This review summarizes the current data on the control of MCHR1 function through glycosylation and phosphorylation, as related to cell function. Especially, a series of mutagenesis study highlights the importance of complete glycosylation of MCHR1 for efficient trafficking to the plasma membrane.

Keywords: melanin-concentrating hormone, structure-function relationship, glycosylation, phosphorylation, G-protein

\section{INTRODUCTION}

The G-protein-coupled receptor (GPCR) gene family is one of the largest families in the mammalian genome. GPCRs are typical heptahelical receptors composed of an extracellular N-terminus, an intracellular C-terminus, and seven transmembrane bundles connected by three intracellular loops and three extracellular loops. Activation of GPCRs induces second messenger responses that change the biochemical properties of the recipient cell and can modulate not only its electrophysiological responsiveness, but also its transcriptional activity. Thus, the diverse signaling and wide array of functions have allowed GPCRs to be employed in the physiological regulation of nearly all biological functions. These features coupled with ligands that are chemically highly specific for the receptors have resulted in the extensive utilization of GPCR-targeted drug design. Furthermore, the dynamic posttranslational modifications may provide tissue-specific functions, since distinct cellular environments or agonists can mediate different effects on receptor signaling or regulation of a number of GPCRs (1-5). Consequently, these regulatory processes may hold the keys to alternative targets for GPCR research. In this article, we focus solely on the posttranslational modification of one GPCR, melanin-concentrating hormone $(\mathrm{MCH})$ receptor, which is one of the potential targets for obesity research.

\section{ROLE OF MCH IN FOOD INTAKE}

Melanin-concentrating hormone was originally discovered as a 17amino-acid neuropeptide in the chum salmon pituitary (6). $\mathrm{MCH}$ is secreted from the pituitary into the circulation, and induces paling of the skin in teleost fish. Mammalian $\mathrm{MCH}$ was subsequently identified as a 19-amino-acid peptide in the rat hypothalamus (7). Although the peptide structures are highly conserved between fish and mammals, no direct effects of $\mathrm{MCH}$ on skin pigmentation in mammals are demonstrable. Mammalian $\mathrm{MCH}$ is predominantly synthesized in the brain, especially in the lateral hypothalamus (LH) and zona incerta with projections to numerous areas in the brain (8). The LH is classically known as the "hunger center," since lesions in this area produce anorexia and stimulation of the area leads to overeating. The important role of $\mathrm{MCH}$ in feeding was supported by a study showing that the $\mathrm{MCH}$ gene is overexpressed upon fasting and in $o b / o b$ leptin-deficient mice (9). Moreover, direct intracerebroventricular administration of $\mathrm{MCH}$ increases food intake in rats, suggesting that $\mathrm{MCH}$ is an orexigenic peptide (9), while chronic infusion of $\mathrm{MCH}$ or $\mathrm{MCH}$ analogs significantly increases food intake, body weight, white adipose tissue mass, and liver mass in mice fed a moderately high-fat diet ad libitum $(10,11)$. Further evidence of the significance of $\mathrm{MCH}$ in feeding came from studying the effects of altering the MCH levels using knockout and overexpression techniques (12-14). It has shown that ablation of functional MCH results in a lean phenotype, increased energy expenditure, and resistance to diet-induced obesity. Such phenotypes are not observed for many other neuropeptides, suggesting a crucial role for $\mathrm{MCH}$ in feeding behavior. On the basis of these data, $\mathrm{MCH}$ appears to be a critical effector of feeding behavior and energy balance.

\section{MCH ACTS THROUGH GPCRs}

Despite the discovery of the MCH peptide, the site of its biological action remained obscure until 1999. At that time, five independent groups, including us, identified that the $\mathrm{MCH}$ receptor (MCHR1) was SLC-1/GPR24, an orphan GPCR, by applying orphan receptor strategies and reverse pharmacology (15-19). MCHR1 belongs to the $\gamma$-group of rhodopsin family class A GPCRs (20), and shows $40 \%$ homology with the somatostatin receptor as its closest neighbor. High expression of MCHR1 mRNA in rats is detected 
in most anatomical areas implicated in the control of olfaction, such as the olfactory nerve layer, olfactory nucleus, and tubercle (21). Strong labeling is also detected in several limbic structures, such as the hippocampal formation, septum, and amygdala, all of which are implicated in the regulation of stress and emotional processes. Furthermore, MCHR1 is abundantly expressed in the nucleus accumbens shell, where it may play roles in the regulation of motivation and reward. In recombinant cell lines, $\mathrm{MCH}$ binds to MCHR1 with affinities of $\sim 1 \mathrm{nM}$, and couples to Gi, Go, and Gq proteins $(15,16,22)$. Thus, activation of MCHR1 leads to increases in intracellular calcium mobilization via both $\mathrm{Gi} / \mathrm{o}-$ and Gq-coupled pathways and to decreased cyclic AMP (cAMP) levels via the Gi/o-coupled pathway. Further analyses of MCHR1 signaling in recombinant cell lines and hippocampal brain slices demonstrated that activation of MCHR1 also leads to extracellular signal-regulated kinase (ERK) phosphorylation (22, 23). Recently, accumulating evidence has supported the notion that receptorbinding partners regulate the magnitude, duration, and spatial components of GPCR signaling. MCHR1-binding proteins have also been detected and described. Periplakin and neurochondrin, which interact with the proximal C-terminus of MCHR1, reduce the capacity to initiate calcium mobilization $(24,25)$. Furthermore, RGS8, one of the GTPase-activating proteins for G $\alpha$ subunits, was identified as a negative regulator. Arg253 and Arg256 at the distal end of the third cytoplasmic loop were found to comprise a structurally important site for the functional interaction with RGS8 (26). Clarification of the physiological consequences of these proteins that interact with the MCHR1 system will be achieved by assessing their coexpressions in the nervous system.

A second $\mathrm{MCH}$ receptor (MCHR2) was subsequently identified by six groups using human genomic sequence searches (27). It shares 38\% amino acid identity with MCHR1 and binds to $\mathrm{MCH}$ with high affinity (28). The distribution of MCHR2 in humans is relatively limited, in that it is expressed in the cerebral cortex, amygdala, and hippocampus, but not in the hypothalamus (29). In contrast to human MCHR1, human MCHR2 only couples to Gq protein, and the signaling is not sensitive to pertussis toxin. Of note, MCHR2 was found to be a pseudogene in rodent species, but is functional in dogs, ferrets, rhesus monkeys, and humans (30). The physiological importance of MCHR2 remains unknown owing to the lack of available animal models. Later studies identified three $\mathrm{MCH}$ receptor sequences in zebrafish and two receptor sequences from fugu, barfin flounder, and goldfish in wholegenome datasets (31-33). Moreover, based on predictions from a preliminary genome assembly of Xenopus tropicalis, information for four $\mathrm{MCH}$ receptors has been obtained (34). Phylogenetic analyses of these receptors suggest that an initial duplication of the $\mathrm{MCH}$ receptor occurred early in evolution, giving rise to MCHR1 and MCHR2. MCH receptors are only found in vertebrates (35). Therefore, the characterization of $\mathrm{MCH}$ receptors from birds and reptiles may serve as a valuable reference to elucidate the role of the $\mathrm{MCH}$ system during evolution.

The gene for prepro $\mathrm{MCH}$ encodes two additional peptides, NEI and NGE of unknown function. MCHR1 is the sole receptor expressed in rodents, MCHR1 knockout mice may provide confirmation of the role of $\mathrm{MCH}$ in energy homeostasis. To date, MCHR1 knockout mice have been reported to exhibit an obesity-prone phenotype $(36,37)$. In contrast to MCH knockout mice, MCHR1 knockout mice remained lean on a regular chow diet. On a high-fat diet, the mice gained less weight, characterized by hyperphagia, hyperactivity, and hypermetabolism. To better understand the role of MCH-MCHR1 system in energy homeostasis, several structurally distinct small molecule antagonists for the MCHR1 have been synthesized and tested in cell-based assays for their selectivity and for in vivo potency in the rodent. Comprehensive review of desired selectivity and efficacy of MCHR1 antagonist in vivo should consult some recent reviews $(38,39)$. The majority of studies indicated that the MCHR1 antagonists are effective in different models of obesity in a variety of different rodent strains, due to inhibition of food intake and/or energy expenditure (40, 41). Overall, both rodent genetic studies and rodent pharmacologic studies on MCHR1 have confirmed the importance of the MCH-MCHR1 system for modulating energy homeostasis. With the broad distribution of MCH fibers and MCHR1 in the rodent brain, the physiological function of the $\mathrm{MCH}$ system is not only restricted to feeding behavior. In accordance with these observations, multiple rodent models have suggested functional implications of the MCH-MCHR1 system in sleep, emotion, and reward effects of psychostimulants (42-45). In peripheral tissues, the MCH-MCHR1 system has been shown to play important roles in pancreatic islet function and intestinal inflammation $(46,47)$.

\section{POSTTRANSLATIONAL CONTROL OF MCH RECEPTORS}

Posttranslational modifications are considered to be the primary regulatory mechanisms of virtually all GPCRs. Since most GPCRs are naturally expressed at low levels, except for rhodopsin, in vitro eukaryotic heterologous expression systems are often employed for their biochemical characterization, including the complex posttranslational modifications.

The most well-understood posttranslational modifications include palmitoylation, glycosylation, and phosphorylation. Most GPCRs are posttranslationally modified with one or more palmitic acids, a 16-carbon saturated fatty acid, covalently bound to cysteine(s) localized in the C-terminal cytoplasmic tail. The insertion of palmitate into the cytoplasmic leaflet of the plasma membrane can create a fourth loop named helix 8 , thereby profoundly affecting the GPCR structure and consequently the interactions with intracellular partner proteins. Although a putative palmitoylation site has not been identified in mammalian MCHR1 (48), the existence of helix 8 was predicted by a computational analysis and its functional importance in the signaling pathway has been experimentally confirmed in HEK293T cells $(49,50)$.

$\mathrm{N}$-linked glycosylation is one of the most common forms of posttranslational modification. The consensus sequences for $\mathrm{N}$ linked glycosylation, Asn-X-Thr and Asn-X-Ser, in which oligosaccharides can bind to the asparagine residues, are found in many GPCRs and are shared by almost all eukaryotic cells, including yeast cells. The significance of these asparagine residues has been demonstrated in various receptors, and they seem to play several important roles including receptor folding, trafficking, and stability, thereby allowing fine-tuning of the receptor function. When Flag-tagged rat MCHR1 is expressed in HEK293 cells, several characteristic immunoreactive bands of $\sim 35-65 \mathrm{kDa}$ are detected by western blotting (51). These molecular weights are 
higher than those predicted from MCHR1 cDNA sequences, suggesting glycosylated forms of MCHR1. This notion is supported by the fact that the N-terminal domain of rat MCHR1 includes three N-glycosylation sites at Asn13, Asn16, and Asn23 (48), all of which are conserved among the goldfish, Xenopus, mouse, and human orthologs (Figure 1). We proved the presence of

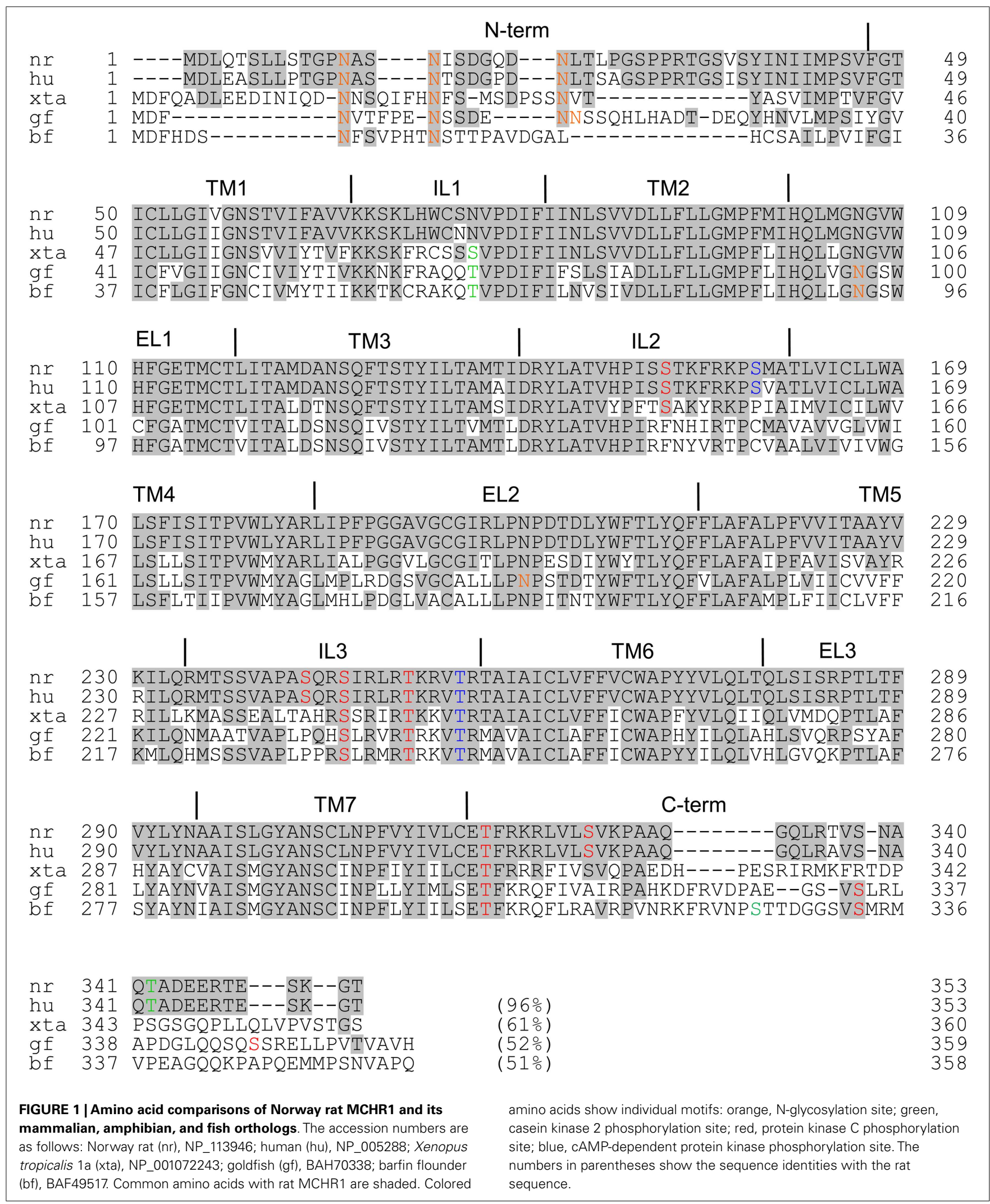


oligosaccharides in MCHR1 by enzymatic treatment. Furthermore, single or multiple mutations of Asn13, Asn16, and Asn23 to $\operatorname{Gln}(\mathrm{N} 23 \mathrm{Q}, \mathrm{N} 13 \mathrm{Q} / \mathrm{N} 16 \mathrm{Q}, \mathrm{N} 13 \mathrm{Q} / \mathrm{N} 23 \mathrm{Q}, \mathrm{N} 16 \mathrm{Q} / \mathrm{N} 23 \mathrm{Q}$, and $\mathrm{N} 13 \mathrm{Q} / \mathrm{N} 16 \mathrm{Q} / \mathrm{N} 23 \mathrm{Q})$ caused pronounced reductions in the levels of glycosylation of the receptor protein, and impaired the receptor expression at the cell surface. In particular, the N-linked glycosylation at Asn23 is necessary for the cell surface expression and signal transduction $(51,52)$. Mutation of residues other than the N-glycosylation sites also caused incomplete glycosylation of MCHR1, and impaired receptor trafficking and signaling. MCHR1 belongs to the rhodopsin family of GPCRs, and the Glu/Asp3.49-Arg3.50-Tyr3.51 (E/DRY) sequence is a highly conserved motif in this family. It was found that substitution of Asp140 or Tyr142 to Ala (D140A and Y142A, respectively) resulted in non-functional receptors without changing the high affinity constant values in HEK293 cells (53). The cell surface expression levels of both mutants were about $40 \%$ of the wild-type MCHR 1 level, with pronounced decreases in the $65-\mathrm{kDa}$ immunoreactive band (highly glycosylated form). Different types of site-directed mutants that exhibited much less glycosylation were found for highly conserved Pro residues at transmembrane regions 2, 4, 5, 6, and 7 (P97A, P177A, P220A, P271A, and P308A, respectively) (Figure 1). These mutations all produced complete loss of signaling with lack of the $65-\mathrm{kDa}$ immunoreactive band in HEK293 cells (50). The importance of proper glycosylation for receptor trafficking and signaling was extensively analyzed using substitution of Thr255 to Ala (T255A), which is located at the junction of intracellular loop 3 and transmembrane region 6 (52). T255A was largely retained in the endoplasmic reticulum (ER) and associated with the chaperon protein calnexin in HEK293 cells. This arose through receptor misfolding, which prevented some Nglycosylation. Interestingly, addition of a small molecule MCHR1 antagonist to T255A- and N13Q/N16Q/N23Q-expressing cells led to functional receptors becoming fully glycosylated at similar extents to wild-type MCHR1. Thus, complete glycosylation of MCHR1 is necessary to allow its efficient trafficking through the ER and Golgi to the plasma membrane.

Ligand-stimulated GPCR activation, desensitization, internalization, and recycling occur in a controlled cyclical process. Since the magnitude and duration of ligand-induced GPCR responses are linked to the balance between signal generation and signal termination, the endocytic pathway that starts with internalization tightly controls the activity of GPCRs. The process of endocytosis is promoted by agonist-induced phosphorylation of receptors. Upon GPCR activation, several sites in GPCRs are immediately phosphorylated by G-protein receptor kinases and other protein kinases. The receptor phosphorylation and subsequent binding of $\beta$-arrestin prevent consequent interactions of the receptors with G-proteins, thereby effectively terminating the G-proteinmediated signaling and initiating the endocytic process. The endocytic activity of arrestin is also subject to dynamic regulation by dephosphorylation and ubiquitination. GPCR phosphorylation usually occurs predominantly on Ser and Thr residues within the C-terminal receptor tail and third intracellular loop. In the intracellular loop of rat MCHR1, there are nine predicted phosphorylation sites, comprising two for protein kinase A (Arg/Lys-Arg/Lys-X-Ser/Thr: S158 and T255), six for protein kinase C (Ser/Thr-X-Arg/Lys: S151, S243, S246, T251, T317, and S325), and one for protein kinase casein kinase 2 (Ser/Thr-XX-Asp/Glu: T342) (Figure 1). It has been described that the Ser and Thr residues are phosphorylated in agonist-independent manners in some GPCRs (54). However, to our knowledge, no previous studies have identified whether MCHR1 is phosphorylated under basal conditions or in response to $\mathrm{MCH}$ using a $\left[{ }^{32} \mathrm{P}\right]$ orthophosphate metabolic pre-labeling approach. On the other hand, the results of a mutational study suggested the importance of several predicted phosphorylation sites in MCHR1 for the receptor function. A triple substituted mutant in the C-terminus, T317A/S325A/T342A, has no effects on the signal transduction in calcium mobilization, but significantly prevents $\mathrm{MCH}$-induced receptor internalization through protein kinase $\mathrm{C}$ and $\beta$-arrestin 2 dependent processes (55). Since S246, T251, and T255 in the third intracellular loop are all conserved in MCHR1 derived from goldfish, Xenopus, mice, and humans (Figure 1), they may play a critical role in receptor function via phosphorylation. The T255A mutation produces a non-functional receptor as described above (52), while the importance of S245 and T251 remains unclear. Thus far, we have preliminary data that point mutations at these residues produce no significant changes in either the cellular localization or calcium mobilization (Honda and Hamamoto, unpublished data). It has been reported that the generation of phosphosite-specific antibodies accompanied by site-directed mutagenesis and chemical kinase inhibitors can provide more direct evidence for phosphorylation in GPCR-expressing cells $(2,3)$. Since rat MCHR1 possesses nine potential phosphorylation sites, a series of phosphate acceptor site-specific antibodies are potentially obtainable to reveal the coordinated biochemical mechanism involving sequential and hierarchical multisite phosphorylation of the receptor, similar to somatostatin or $\mu$ opioid receptors $(4,56)$.

\section{FUTURE DIRECTIONS}

The MCH-MCHR1 system has integral roles in many cellular events, and represents an important therapeutic target. For example, it may be targeted in strategies for developing treatments against obesity and mood disorders, and possibly also for inflammatory diseases. Therefore, the regulation of the $\mathrm{MCH}$ system by posttranslational modifications remains an emerging area at the nexus of endocrinology with important implications for drug development. However, our understanding of the regulation of MCHR1 signaling by glycosylation and phosphorylation is limited (Table 1). At present, several methodological advances could facilitate analyses of GPCR posttranslational modifications. In particular, significant improvements have been achieved in mass spectrometry (MS) and related procedures such as tandem MS or chemical microsequencing, such that MS is becoming a major tool for analyzing posttranslational modifications. Since purification of hydrophobic membrane proteins has been enhanced by the utilization of specific detergents and several enrichment procedures, MS analyses could have broad utility, such as direct identification of glycosylated or phosphorylated residues, even for low amounts in GPCRs $(1,5,57,58)$. Moreover, it has been shown that distinct cellular environments can mediate different glycosylation patterns in rhodopsin and serotonin receptor type 4 (5). For example, rhodopsin is heavily and heterogeneously glycosylated 
Table 1 | Posttranslational modifications with cellular function in mammal MCHR1.

\begin{tabular}{|c|c|c|c|c|}
\hline Region & & Mutant receptor & Impact on MCHR1 in HEK293 cells & Reference \\
\hline \multirow[t]{5}{*}{ Extracellular $\mathrm{N}$-terminus } & & $\mathrm{N} 23 \mathrm{Q}^{\mathrm{a}}$ & & \\
\hline & & N130/N160a & $\Downarrow$ Mature glycosylation & \\
\hline & & $\mathrm{N} 130 / \mathrm{N}^{23 \mathrm{O}^{\mathrm{a}}}$ & $\Downarrow$ Cell surface expression & $(51,52)$ \\
\hline & & $\mathrm{N} 16 \mathrm{Q} / \mathrm{N} 23 \mathrm{Q}^{\mathrm{a}}$ & $\Downarrow \mathrm{Ca}^{2+}$ mobilization & \\
\hline & & $\mathrm{N} 130 / \mathrm{N} 16 \mathrm{Q} / \mathrm{N} 23 \mathrm{Q}^{\mathrm{a}}$ & & \\
\hline \multirow[t]{3}{*}{ Intracellular loop 2} & & D140A & $\Downarrow$ Mature glycosylation & $(53)$ \\
\hline & & Y142A & $\Downarrow$ Cell surface expression & \\
\hline & & & Loss of function ( $\mathrm{Ca}^{2+}$ mobilization, cAMP inhibition, ERK activation) & \\
\hline \multirow[t]{5}{*}{ Transmembrane region } & 2 & P97A & \multirow{5}{*}{$\begin{array}{l}\Downarrow \text { Mature glycosylation } \\
\text { Loss of function }\left(\mathrm{Ca}^{2+} \text { mobilization) }\right.\end{array}$} & \\
\hline & 4 & P177A & & \\
\hline & 5 & P220A & & \\
\hline & 6 & P271A & & \\
\hline & 7 & P308A & & $(50)$ \\
\hline \multirow{3}{*}{$\begin{array}{l}\text { Junction of intracellular loop } 3 \\
\text { and transmembrane region } 6\end{array}$} & & $\mathrm{~T} 255 \mathrm{~A}^{\mathrm{b}}$ & $\Downarrow$ Mature glycosylation & $(52)$ \\
\hline & & & $\Downarrow$ Cell surface expression (retained in the ER) & \\
\hline & & & Loss of function ( $\mathrm{Ca}^{2+}$ mobilization) & \\
\hline \multirow[t]{2}{*}{ Intracellular C-terminus } & & T317A/S325A/T342A & $\rightarrow \mathrm{Ca}^{2+}$ mobilization & $(55)$ \\
\hline & & & $\Downarrow$ Receptor internalization (protein kinase $C$ and $\beta$-arrestin 2-dependent) & \\
\hline
\end{tabular}

${ }^{a}$ The consensus sequences for $N$-linked glycosylation.

${ }^{b}$ Predicted phosphorylation sites.

when expressed in HEK293 and COS-1 cells, but shows a sparser and more homogeneous glycosylation pattern in its native retinal tissue. Thus, these features remind us of the significant importance

\section{REFERENCES}

1. Trester-Zedlitz M, Burlingame A, Kobilka B, von Zastrow M. Mass spectrometric analysis of agonist effects on posttranslational modifications of the beta-2 adrenoceptor in mammalian cells. Biochemistry (2005) 44:6133-43. doi: 10.1021/bi0475469

2. Nagel F, Doll C, Pöll F, Kliewer A, Schröder H, Schulz S. Structural determinants of agonist-selective signaling at the sst(2A) somatostatin receptor. $\mathrm{Mol}$ Endocrinol (2011) 25:859-66. doi:10.1210/me. 2010-0407

3. Petrich A, Mann A, Kliewer A, Nagel F, Strigli A, Märtens JC, et al. Phosphorylation of threonine 333 regulates trafficking of the human sst5 somatostatin receptor. Mol Endocrinol (2013) 27:671-82. doi:10.1210/me.2012-1329

4. Just S, Illing S, Trester-Zedlitz M, Lau EK, Kotowski SJ, Miess E, et al. Differentiation of opioid drug effects by hierarchical multi-site phosphorylation. Mol Pharmacol (2013) 83:633-9. doi:10.1124/mol. 112.082875
5. Salom D, Wang B, Dong Z, Sun W, Padayatti P, Jordan S, et al. Posttranslational modifications of the serotonin type 4 receptor heterologously expressed in mouse rod cells. Biochemistry (2012) 51:214-24. doi: 10.1021/bi201707y

6. Kawauchi H, Kawazoe I, Tsubokawa M, Kishida M, Baker BI. Characterization of melanin-concentrating hormone in chum salmon pituitaries. Nature (1983) 305:321-3. doi:10.1038/305321a0

7. Vaughan JM, Fischer WH, Hoeger C, Rivier J, Vale W. Characterization of melanin-concentrating hormone from rat hypothalamus. Endocrinology (1989) 125:1660-5. doi:10.1210/endo-125-3-1660

8. Bittencourt JC, Presse F, Arias C, Peto C, Vaughan J, Nahon JL, et al. The melanin-concentrating hormone system of the rat brain: an immuno- and hybridization histochemical characterization. J Comp Neurol (1992) 319:218-45. doi:10. 1002/cne.903190204

9. $\mathrm{Qu}$ D, Ludwig DS, Gammeltoft S, Piper M, Pelleymounter MA, Cullen MJ, et al. A role for

of studying both heterologous and natural expression systems, and offer a comprehensive view of the posttranslational modifications in MCHR1.

melanin-concentrating hormone in the central regulation of feeding behaviour. Nature (1996) 380:243-7. doi:10.1038/380243a0

10. Rossi M, Choi SJ, O’Shea D, Miyoshi T, Ghatei MA, Bloom SR. Melanin-concentrating hormone acutely stimulates feeding, but chronic administration has no effect on body weight. Endocrinology (1997) 138:351-5. doi:10.1210/ en.138.1.351

11. Ito $\mathrm{M}$, Gomori A, Ishihara $\mathrm{A}$ Oda Z, Mashiko S, Matsushita H, et al. Characterization of $\mathrm{MCH}$ mediated obesity in mice. Am J Physiol Endocrinol Metab (2003) 284:E940-5. doi:10.1152/ajpendo. 00529.2002

12. Shimada M, Tritos NA, Lowell BB, Flier JS, Maratos-Flier E. Mice lacking melanin-concentrating hormone are hypophagic and lean. Nature (1998) 396:670-4. doi:10. 1038/25341

13. Ludwig DS, Tritos NA, Mastaitis JW, Kulkarni R, Kokkotou E, Elmquist $\mathrm{J}$, et al. Melanin-concentrating hormone overexpression in transgenic mice leads to obesity and insulin resistance. J Clin Invest (2001) 107:379-86. doi:10.1172/ JCI10660

14. Alon T, Friedman JM. Late-onset leanness in mice with targeted ablation of melanin concentrating hormone neurons. $\mathrm{I} \mathrm{Neu}$ rosci (2006) 26:389-97. doi:10. 1523/JNEUROSCI.1203-05.2006

15. Chambers J, Ames RS, Bergsma D, Muir A, Fitzgerald LR, Hervieu G, et al. Melanin-concentrating hormone is the cognate ligand for the orphan G-protein-coupled receptor SLC-1. Nature (1999) 400:261-5. doi:10.1038/22313

16. Saito Y, Nothacker HP, Wang $\mathrm{Z}$, Lin SH, Leslie F, Civelli O. Molecular characterization of the melanin-concentrating-hormone receptor. Nature (1999) 400:265-9. doi: $10.1038 / 22321$

17. Shimomura Y, Mori M, Sugo T, Ishibashi $\mathrm{Y}$, Abe M, Kurokawa T, et al. Isolation and identification of melanin-concentrating hormone as the endogenous ligand of the SLC1 receptor. Biochem Biophys Res Commun (1999) 261:622-6. doi:10. 1006/bbrc. 1999.1104 
18. Bächner D, Kreienkamp H, Weise C, Buck F, Richter D. Identification of melanin concentrating hormone $(\mathrm{MCH})$ as the natural ligand for the orphan somatostatin-like receptor 1 (SLC1). FEBS Lett (1999) 457:522-4. doi:10.1016/S0014-5793(99) 01092-3

19. Lembo PM, Grazzini E, Cao J, Hubatsch DA, Pelletier M, Hoffert $\mathrm{C}$, et al. The receptor for the orexigenic peptide melaninconcentrating hormone is a Gprotein-coupled receptor. Nat Cell Biol (1999) 1:267-71. doi:10.1038/ 12978

20. Fredriksson R, Lagerström MC, Lundin LG, Schiöth HB. The Gprotein-coupled receptors in the human genome form five main families. Phylogenetic analysis, paralogon groups, and fingerprints. $\mathrm{Mol}$ Pharmacol (2003) 63:1256-72. doi: 10.1124/mol.63.6.1256

21. Saito Y, Cheng M, Leslie FM, Civelli O. Expression of the melaninconcentrating hormone $(\mathrm{MCH})$ receptor mRNA in the rat brain. J Comp Neurol (2001) 435:26-40. doi: $10.1002 / \mathrm{cne} .1191$

22. Hawes BE, Kil E, Green B, O'Neill K, Fried S, Graziano MP. The melaninconcentrating hormone couples to multiple $G$ proteins to activate diverse intracellular signaling pathways. Endocrinology (2000) 141:4524-32. doi:10.1210/en.141. 12.4524

23. Pissios P, Trombly DJ, Tzameli I, Maratos-Flier E. Melaninconcentrating hormone receptor 1 activates extracellular signalregulated kinase and synergizes with Gs-coupled pathways. Endocrinology (2003) 144:3514-23. doi:10.1210/en.2002-0004

24. Murdoch H, Feng GJ, Bachner D, Ormiston L, White JH, Richter D, et al. Periplakin interferes with G protein activation by the melaninconcentrating hormone receptor-1 by binding to the proximal segment of the receptor C-terminal tail. J Biol Chem (2005) 280:8208-20. doi:10. 1074/jbc.M405215200

25. Francke F, Ward RJ, Jenkins L, Kellett E, Richter D, Milligan $\mathrm{G}$, et al. Interaction of neurochondrin with the melaninconcentrating hormone receptor 1 interferes with $G$ protein-coupled signal transduction but not agonistmediated internalization. J Biol Chem (2006) 281:32496-507. doi: 10.1074/jbc.M602889200

26. Miyamoto-Matsubara M, Saitoh O, Maruyama K, Aizaki Y,
Saito Y. Regulation of melaninconcentrating hormone receptor 1 signaling by RGS8 with the receptor third intracellular loop. Cell Signal (2008) 20: 2084-94. doi:10.1016/j.cellsig.2008. 07.019

27. An S, Cutler G, Zhao JJ, Huang SG, Tian H, Li W, et al. Identification and characterization of a melanin-concentrating hormone receptor. Proc Natl Acad Sci U S A (2001) 98:7576-81. doi:10.1073/ pnas. 131200698

28. Sailer AW, Sano H, Zeng Z, McDonald TP, Pan J, Pong SS, et al. Identification and characterization of a second melanin-concentrating hormone receptor, $\mathrm{MCH}-2 \mathrm{R}$. Proc Nat Acad Sci U S A (2001) 98:7564-9. doi:10.1073/pnas.121170598

29. Hill J, Duckworth M, Murdock P, Rennie G, Sabido-David C, Ames RS, et al. Molecular cloning and functional characterization of $\mathrm{MCH} 2$, a novel human $\mathrm{MCH}$ receptor. $J$ Biol Chem (2001) 276:20125-9. doi:10.1074/jbc.M102068200

30. Tan CP, Sano H, Iwaasa $H$, Pan J, Sailer AW, Hreniuk DL, et al. Melanin-concentrating hormone receptor subtypes 1 and 2: species-specific gene expression. Genomics (2002) 79:785-92. doi:10. 1006/geno.2002.6771

31. Logan DW, Bryson-Richardson RJ, Pagán KE, Taylor MS, Currie PD, Jackson IJ. The structure and evolution of the melanocortin and $\mathrm{MCH}$ receptors in fish and mammals. Genomics (2003) 81:184-91. doi:10. 1016/S0888-7543(02)00037-X

32. Takahashi A, Kosugi T, Kobayashi Y, Yamanome T, Schiöth HB, Kawauchi H. The melaninconcentrating hormone receptor 2 (MCH-R2) mediates the effect of $\mathrm{MCH}$ to control body color for background adaptation in the barfin flounder. Gen Comp Endocrinol (2007) 151:210-9. doi:10.1016/j.ygcen.2007.01.011

33. Mizusawa K, Saito Y, Wang Z, Kobayashi Y, Matsuda K, Takahashi A. Molecular cloning and expression of two melanin-concentrating hormone receptors in goldfish. Peptides (2009) 30:1990-6. doi:10. 1016/j.peptides.2009.04.010

34. Ji Y, Zhang Z, Hu Y. The repertoire of G-protein-coupled receptors in Xenopus tropicalis. BMC Genomics (2009) 10:263. doi:10.1186/14712164-10-263

35. Fredriksson R, Schiöth HB. The repertoire of G-proteincoupled receptors in fully sequenced genomes. Mol Pharmacol (2005) 67:1414-25. doi:10.1124/mol.104.009001

36. Chen Y, Hu C, Hsu CK, Zhang Q, Bi C, Asnicar M, et al. Targeted disruption of the melaninconcentrating hormone receptor1 results in hyperphagia and resistance to diet-induced obesity. Endocrinology (2002) 143:2469-77. doi:10.1210/en.143.7.2469

37. Marsh DJ, Weingarth DT, Novi DE, Chen HY, Trumbauer ME, Chen AS, et al. Melanin-concentrating hormone 1 receptor-deficient mice are lean, hyperactive, and hyperphagic and have altered metabolism. Proc Natl Acad Sci U S A (2002) 99:3240-5. doi:10.1073/ pnas.052706899

38. Luthin DR. Anti-obesity effects of small molecule melaninconcentrating hormone receptor 1 (MCHR1) antagonists. Life Sci (2007) 81:423-40. doi:10.1016/j.lfs.2007.05.029

39. MacNeil DJ. The role of melaninconcentrating hormone and its receptors in energy homeostasis. Front Endocrinol (Lausanne) (2013) 4:49. doi:10.3389/fendo.2013.00049

40. Takekawa S, Asami A, Ishihara Y, Terauchi J, Kato K, Shimomura Y, et al. T-226296: a novel, orally active and selective melaninconcentrating hormone receptor antagonist. Eur J Pharmacol (2002) 438:129-35. doi:10.1016/S00142999(02)01314-6

41. Gehlert DR, Rasmussen K, Shaw J, Li X, Ardayfio P, Craft L, et al. Preclinical evaluation of melaninconcentrating hormone receptor 1 antagonism for the treatment of obesity and depression. J Pharmacol Exp Ther (2009) 329:429-38. doi:10.1124/jpet.108.143362

42. Borowsky B, Durkin MM, Ogozalek K, Marzabadi MR, DeLeon J, Lagu B, et al. Antidepressant, anxiolytic and anorectic effects of a melanin-concentrating hormone-1 receptor antagonist. Nat Med (2002) 8:825-30. doi:10.1038/nm0902-1039b

43. Verret L, Goutagny R, Fort $P$, Cagnon L, Salvert D, Léger L, et al. A role of melanin-concentrating hormone producing neurons in the central regulation of paradoxical sleep. BMC Neurosci (2003) 4:19. doi:10.1186/1471-2202-4-19

44. Antal-Zimanyi I, Khawaja X. The role of melanin-concentrating hormone in energy homeostasis and mood disorders. J Mol $\mathrm{Neu}$ rosci (2009) 39:86-98. doi:10.1007/ s12031-009-9207-6
45. Chung S, Saito Y, Civelli O. $\mathrm{MCH}$ receptors/gene structure-in vivo expression. Peptides (2009) 30:1985-9. doi:10.1016/j.peptides.2009.07.017

46. Pissios P, Ozcan U, Kokkotou E, Okada T, Liew CW, Liu S, et al. Melanin concentrating hormone is a novel regulator of islet function and growth. Diabetes (2007) 56:311-9. doi:10.2337/db06-0708

47. Kokkotou E, Moss AC, Torres D, Karagiannides I, Cheifetz A, Liu S, et al. Melanin-concentrating hormone as a mediator of intestinal inflammation. Proc Natl Acad Sci U S A (2008) 105:10613-8. doi:10. 1073/pnas.0804536105

48. Lakaye B, Minet A, Zorzi W, Grisar T. Cloning of the rat brain cDNA encoding for the SLC-1 $\mathrm{G}$ protein-coupled receptor reveals the presence of an intron in the gene. Biochim Biophys Acta (1998) 1401:216-20. doi:10.1016/ S0167-4889(97)00135-3

49. Tetsuka M, Saito Y, Imai K, Doi $\mathrm{H}$, Maruyama $\mathrm{K}$. The basic residues in the membrane-proximal Cterminal tail of the rat melaninconcentrating hormone receptor 1 are required for receptor function. Endocrinology (2004) 145:3712-23. doi:10.1210/en.2003-1638

50. Hamamoto A, Horikawa M, Saho T, Saito Y. Mutation of Phe 318 within the $\operatorname{NPxxY}(\mathrm{x})(5,6) \mathrm{F}$ motif in melanin-concentrating hormone receptor 1 results in an efficient signaling activity. Front Endocrinol (Lausanne) (2012) 3:147. doi:10. 3389/fendo.2012.00147

51. Saito Y, Tetsuka M, Yue L, Kawamura Y, Maruyama K. Functional role of $N$-linked glycosylation on the rat melaninconcentrating hormone receptor 1 . FEBS Lett (2003) 533:29-34. doi:10. 1016/S0014-5793(02)03744-4

52. Fan J, Perry SJ, Gao Y, Schwarz DA, Maki RA. A point mutation in the human melanin concentrating hormone receptor 1 reveals an important domain for cellular trafficking. Mol Endocrinol (2005) 19:2579-90. doi:10.1210/me.2004-0301

53. Aizaki Y, Maruyama K, NakanoTetsuka M, Saito Y. Distinct roles of the DRY motif in rat melaninconcentrating hormone receptor 1 in signaling control. Peptides (2009) 30:974-81. doi:10.1016/j.peptides. 2009.01.017

54. Mokros T, Rehm A, Droese J, Oppermann M, Lipp M, Höpken UE. Surface expression and endocytosis of the human cytomegalovirusencoded chemokine receptor 
US28 is regulated by agonistindependent phosphorylation. $J$ Biol Chem (2002) 277:45122-8. doi:10.1074/jbc.M208214200

55. Saito Y, Tetsuka M, Li Y, Kurose $\mathrm{H}$, Maruyama K. Properties of rat melanin-concentrating hormone receptor 1 internalization. Peptides (2004) 25:1597-604. doi:10.1016/j.peptides.2004.03.026

56. Ghosh M, Schonbrunn A. Differential temporal and spatial regulation of somatostatin receptor phosphorylation and dephosphorylation. J Biol Chem (2011) 286: 13561-73. doi:10.1074/jbc.M110. 215723
57. Lau EK, Trester-Zedlitz M, Trinidad JC, Kotowski SJ, Krutchinsky AN, Burlingame AL, et al. Quantitative encoding of a partial agonist effect on individual opioid receptors by multi-site phosphorylation and threshold detection. Sci Signal (2011) 9:ra52. doi:10.1126/ scisignal.2001748

58. Heo S, Yang JW, Huber ML, Planyavsky M, Bennett KL, Lubec G. Mass spectrometric characterization of recombinant rat 5-hydroxytryptamine receptor $1 \mathrm{~A} \quad(5-\mathrm{HT}(1 \mathrm{~A}) \mathrm{R})$ expressed in tsA201 human embryonic kidney cells. Proteomics (2012)
12:3338-42. doi:10.1002/pmic. 201200183

Conflict of Interest Statement: The authors declare that the research was conducted in the absence of any commercial or financial relationships that could be construed as a potential conflict of interest.

Received: 22 September 2013; accepted: 07 October 2013; published online: 21 October 2013.

Citation: Saito Y, Hamamoto $A$ and Kobayashi Y (2013) Regulated control of melanin-concentrating hormone receptor 1 through posttranslational modifications. Front. Endocrinol. 4:154. doi: 10.3389/fendo.2013.00154

This article was submitted to Experimental Endocrinology, a section of the journal Frontiers in Endocrinology.

Copyright (c) 2013 Saito, Hamamoto and Kobayashi. This is an open-access article distributed under the terms of the Creative Commons Attribution License (CC $B Y)$. The use, distribution or reproduction in other forums is permitted, provided the original author(s) or licensor are credited and that the original publication in this journal is cited, in accordance with accepted academic practice. No use, distribution or reproduction is permitted which does not comply with these terms. 